Н. В. Леонова

\title{
ЕКСПРЕСИВНІСТЬ ЯК ФУНСКЦІОНАЛЬНА ВЛАСТИВІСТЬ НОМІНАТИВНИХ СИНТАКСИЧНИХ КОНСТРУКЦІЙ-МЖФІ
}

Леонова Н. В. Експресивність як функціональна властивість номінативних синтаксичних конструкцій-МЖФІ.

У статті розглядаються номінативні синтаксичні конструкції, як ще один вид малих жанрових форм інформації та функціональні особливості, притаманні зазначеним синтаксичним одиницям.

Ключові слова: МЖФІ, номінативні синтаксичні конструкції (НСК), експресивність номінативних побудов, експресивний синтаксис МЖФІ.

Леонова Н. В. Экспрессивность как функциональное свойство номинативних синтаксических конструкцій-МЖФИ.

В статье рассматриваются номинативные синтаксические конструкции, как еще один вид малых жанровых форм информации и функциональные особенності, присущие указанным синтаксическим единицам.

Ключевые слова: МЖФИ, номинативные синтаксические конструкции (НСК), экспрессивность номинативных построений, експрессивный синтаксис МЖФИ.

Leonova N. V. Expressivity as a functional property of nominative syntactic structures-MZHFI.

In the article the nominative syntax, as another kind of small genre forms of information and functionality osobennosti inherent specified syntactic units.

Key words: MZHFI, nominative syntax (NS), expressiveness nominative constructions, ekspressivny MZHFI syntax.

У сучасному синтаксисі функціонують кілька тлумачень експресивності, що відрізняються одне від одного різними уявленнями про обсяг цього поняття. Експресивність як загальномовна категорія торкається всіх сфер мови і арсенал ії виражальних засобів є надзвичайно широким.

У широкому розумінні експресивність постає як ментально-емпатична мовленнєва категорія, що реалізується в таких конкретних категоріях, як інтенсивність, цінність, емоційність, образність (Д. Баранник, А. Загнітко, В. Мороз та ін.). Під час взаємодії та впливу один на одного названі компоненти експресивності беруть участь у створенні експресивних синтаксичних одиниць або тексту. Вони можуть доповнювати один одного чи функціонувати окремо. У вузькому розумінні експресивність може позиціонуватися як зрощення 3 оцінними якостями мовлення (А. Єфімов), 3 додатковим змістовим забарвленням, що розуміється як компонент, який належить до основного значення слова та його граматичних форм - емфазою. Останнім часом деякі дослідники зазначають таке явище як обмеження поняття експресивності, що може бути пов'язане з виключенням із його складу 
категорії емоційності, з визнанням категорії експресивності та емоційності не взаємопов'язаними, а взаємодоповнюваними (М. Кожина, Ю. Осипов, М. Степанова, В. Чабаненко та ін.) [5, с. 10].

У сучасній українській літературній мові функціонує багато видів малих жанрових форм інформації (МЖФI): повідомлення в мережах мобільного зв'язку, оголошення та звертання голови зборів, засідань, оголошення автоінформатора на залізничних вокзалах, оголошення ведучих масових заходів тощо. У поданій статті ми розглянемо означену проблему на прикладі оголошення ведучих масових заходів.

Актуальність дослідження експресивності як функціональної властивості номінативних синтаксичних конструкцій (НСК)-МЖФІ зумовлена загальною тенденцією сучасних лінгвістичних досліджень до багатоаспектного аналізу інформаційного тексту та дослідження номінативних речень не лише як статичних одиниць, а й як одиниць контекстуальних, тобто їх функціонування i використання, вплив речень досліджуваного типу на стиль i ритм інформаційних і публіцистичних масивів.

У дев'яностих роках XX-го сторіччя лінгвісти почали оперувати поняттям «експресивний синтаксис» і напрямки дослідження цього явища набувають динамічного розвитку. Інтенсивне вивченням структури малих жанрових форм інформації та їх структурних елементів: тексту,речення, різних аспектів розмовної, усно-діалогічної комунікації, мовної особистості як суб’єкта мовленнєвої діяльності, стосунків адресанта й адресата під час комунікативного акту, засобів підсилення впливу мовлення на співрозмовника, $\epsilon$ підгрунтям для актуалізації цього питання. Не слід забувати про значущість відмежування синтаксичного рівня експресивності МЖФІ від лексичного. На синтаксичному рівні експресивність є функціональною властивістю синтаксичних конструкцій МЖФІ як інформаційних, так і неінформаційних, що може посилювати прагматичну і власне граматичну інформацію висловлення чи його частин, адже синтаксична експресивність є абстрактнішою порівняно 3 лексичною експресивністю. На лексичному ж рівні експресивність виступає як компонент значення слова або як значення слова взагалі.

Дослідження експресивного синтаксису в сучасному мовознавстві здійснюється двома шляхами. Перший пов'язаний з працями видатного мовознавця В. Виноградова, який виокремлює суб'єктивно-експресивні й об'єктивні форми синтаксису. Явище експресії, закладене в синтаксисі, В. Виноградов поєднує 3 суб'єктивно-експресивними формами. Серед засобів експресивного синтаксису мовознавець виділяє інверсивні та приєднувальні конструкції. Другий напрям - поєднання експресивного 3 поняттям суб'єктивної модальності. Дослідженню експресивно-модальних значень синтаксичних конструкцій в усному мовленні присвячені праці Н. Шведової та ін. На сучасному етапі інтенсивно досліджується арсенал експресивних конструкцій усного літературного мовлення. 
Усне мовлення має значно ширший потенціал вираження емоційності порівняно $з$ писемним. Номінативні побудови, як одиниці мовлення, $є$ дійсними носіями спілкування, а в умовах динамічного синтаксису системами функціональної перспективи висловлення.

Питання про системність експресивних явищ, що належать також до галузі синтаксису, заслуговує на увагу, зважаючи на те, що сучасна мовознавча наука веде активні пошуки системності мовних явищ на всіх рівнях мовної структури (І. Вихованець, А. Загнітко, М. Кожина, О. Лаптева, Т. Мелкумова, Н. Шведова та ін.) [3, 4, 5]. В україністиці до цього часу не існує повного монографічного дослідження функціонування номінативних конструкцій МЖФІ як засобів експресивного синтаксису та засобів репрезентації експресії на синтаксичному рівні. Вивченню окремих експресивних одиниць присвячені праці багатьох лінгвістів. Сегментовані конструкції досліджували: Л. Кадомцева, В. Мороз, О. Попов, М. Харченко та ін. Парцельовані побудови вивчали: А. Загнітко, С. Марич, В. Рінберг, Ю. Старовойт та ін. Лексичні повтори 3 синтаксичним поширенням аналізували: Г. Акімова, О. Сковородников та ін.

Досліджуючи питання експресивності як функціональної властивості номінативних синтаксичних конструкцій-МЖФІ, слід враховувати й грунтуватися на таких загальноприйнятих у лінгвістиці положеннях, на яких наголошує відомий мовознавець 3. Коцюба:

- НСК в українській мові за своєю синтаксичною сутністю $\epsilon$ інгерентно експресивні; вони виділяються серед інших синтаксичних одиниць як своєю формою, так і стилістичною семантикою;

- конвергенція здебільшого поєднується з кількісною дивергенцією і структурні схеми непоширених i поширених НСК української літературної мови виявляють ознаки конвергенції та дивергенції; в українській мові речення цього типу можуть бути неповними;

- у сучасному мовознавстві виокремлюють буттєві, вказівні, оцінні НСК, що мають різний ступінь контекстуальної залежності: повну контекстуальну зумовленість буттєвих НСК та оцінних речень непоширених моделей, автосемантичність більшості поширених оцінних і вказівних речень;

- при необхідності заміни двоскладних і односкладних речень та еквівалентів речень НСК може відігравати роль компенсаційного засобу; зазначені побудови можуть компенсувати втрату риторичного запитання чи інверсії.

Більшість сучасних дослідників, які аналізували НСК, уважають їх односкладною моделлю простого речення. Це, зокрема, україністи I. Вихованець, Л. Біятенко, русисти Я. Рословець, Ф. Буженик і навіть англісти О. Старикова, І. Корунець, Б. Ільїш, О. Гаврилюк. Уважається, що НСК є одним із типів односкладних речень 3 єдиним центром, що поєднує в собі якості підмета й присудка.

() Н. В. Леонова, 2013. 
Здебільшого головний член НСК містить двочленну думку, одна частина якої - поняття будь-якого конкретного предмета, інша - віртуальне поняття буття цього предмета. Основне модальне значення, що $є$ необхідним атрибутом експресивності НСК, на думку таких дослідників як Л. Булаховський, Е. Мороховська, О. Старикова, Б. Кулик, А. Загнітко, І. Слинько, Л. Майорова, О. Гаврилюк, І. Сушинська та ін., які досліджували питання статусу НСК це ствердження існування реального факту. Грунтуючись на цьому, слід зауважити, що часова віднесеність НСК є або відносною, або абсолютною.

Визначення і назва НСК походить від латинського терміна casus nominativus за граматичною природою головного члена відповідно до морфологічної форми його вираження. Виходячи 3 цього, можемо говорити, що номінативними є односкладні речення з головним членом, вираженим іменником у формі називного відмінка чи кількісноіменниковим словосполученням, що виконують різноманітні семантикограматичні функції. Не слід відкидати того, що в НР можлива також оклична інтонація, зокрема, оклично-констатувальна. Напр.: X-фактор! 3-й сезон!; 03! Номер 7766!; Прямий ефір. Частина I [7].

Більшість дослідників схиляється до думки, що переважно НСК складаються з одного головного члена: простого чи складеного (непоширені одиниці) або 3 головного члена та залежних від нього неядрових компонентів (поширені конструкції). Структурно дивергентними ознаками НСК $є: 1)$ моделі з постпозитивним прикметником у функції означення: 2) структурні схеми з частками; 3) моделі з іменниками у постпозиції до головного члена, що виконують функцію неузгодженого означення (поєднання безприйменникове); 4) речення з непрямим додатком при головному члені; 5) речення з неузгодженим означенням у препозиції до головного члена.

Попередній аналіз синтаксичних особливостей номінативних синтаксичних конструкцій-МЖФІ показав, що побудови експресивного та розмовного синтаксису сприяють ефективному виконанню завдань НСК-МЖФІ, виконуючи також комунікативну та естетичну функції. Різні синтаксичні конструкції розмовної мови допомагають зробити повідомлення зрозумілим, встановити контакт з аудиторією, привернути iii увагую. Аналізовані одиниці - номінативні побудови ставлять цілий ряд проблемних питань, що виникають під аналізу експресивності як їх функціональної властивості, зокрема щодо реченнєвого статусу, можливості явищ парцеляції та приєднання у структурі НСК, способу лексичного вираження базової частини парцельованих конструкційномінативів, «номінативу ведучого» як спецтипу зазначених побудов; функціонально-семантичних типів зазначених експресивних побудов.

Найбільш уживані в інформаційних текстах різних типів розмовні конструкції - це звернення, еліптичні, питально-відповідальні єдності, повтори. Рідше використовуються коммунікативи, вставні конструкції. 
Особливістю НСК-МЖФІ, що функціонують в інформаційній сфері спілкування є те, що, імітуючи безпосередність і дружність побутових діалогів у мові ведучих заходами: концертів, шоу, телевізійних масових проектів, малі жанрові форми інформації, зокрема й виражені номінативними конструкціями, згадані одиниці зближуються 3 повсякденним мовленням надширокої аудиторії, полегшуючи сприйняття тексту МЖФІ. Напр.: Група «Tри D»!; Сенсачія вечора! Молодиі!; Яків Головко!; Дмитро Політов!; «Лісапєтний батальйон»!; Колектив «Віола»!; Дівчата Олена і Поліна Ніколаєнко!; Фіналістка п'ятого сезону Катя Соколенко!!!; Головне шоу краӥни! [7].

Конструкції експресивного синтаксису (еліптичні, сегментовані, парцельовані та ін) підсилюють ефект впливу на цільову аудиторію - глядачів і слухачів. Значний заряд експресії також несуть складні речення, основою яких $є$ односкладні синтаксичні структури. Односкладні речення із семантикою, що охоплює риси характеру, фізичні та психічні стани людини і поєднуються з НСК у складні безсполучникові конструкції: ...ось трясешся. Сумніви твої, сльози, настрій...; Сила! Міць! Незламність! Серьога у головному шоу країни - п'ятому сезоні X-фактора! [5].

До повної або часткової втрати чи зниження експресивності призводить поєднання НСК із реченнями інших структурних типів, а також оформлення їх у вигляді другорядних членів наступного чи попереднього речення. Формально-синтаксичною особливістю НСК-ЖЖФІ є використання у них речень з імпліцитно вираженим суб'єктом, номінативных речень, зокрема й виражених віддієслівними процесуальними іменниками; еліптичних конструкцій тощо [1, с. 10].

Дослідження й систематизація кспресивності як функціональної властивості номінативних синтаксичних конструкцій-МЖФІ безпосередньо залежить від класифікації номінативних побудов. Номінативні синтаксичні конструкції-МЖФІ як і НСК-загальномовні побудови класифікувалися на основі різних принципів, часто непослідовно. Для детального аналізу проблеми слід зупинитися на окремих класифікаціях НР, укладених вченимимовознавцями за останні сто-сто чотирнадцять років. У деяких посібниках виділяється тільки один тип односкладних речень - безсуб'єктні, у яких суб’єкт (підмет) не потрібний, а єдиний наявний головний член - це присудок. Речення без підмета визначаються як неповні, а щодо речень без присудка констатується, що останній у жодному разі не може бути відсутнім: якщо немає присудка, то немає і речення (див. роботи Є.Будде та ін.). Граматична форма слова $є$ визначальним елементом. Усі побудови і висновки зумовлюються лише нею.

Класифікація НСК, упорядкована В. Бабайцевою та ін., грунтується на основі семантичного принципу. Класифікація В. Бабайцевої вважається найповнішою і вміщує сім типів НСК: 1) буттєві або описові; 2) вказівні; 3) оцінно-буттєві; 4) власне називні; 5) називний уявлення; 6) спонукально-

(ㄱ.․В.Леонова, 2013. 
побажальні; 7) вокативні. У класифікаціях цього типу семантична структура НСК $є$ актуалізованою підставою для відмежування номінативних речень від подібних до них за формою синтаксичних одиниць іменного класу і виявлення різних типів структурно-семантичних варіантів номінативних побудов і доповнення їх систематизації правилами внутрішньої організацї та розширення меж з позиції змісту [2]. Семантичний підхід до класифікації НСК дозволяє виявити категорійні ознаки, а це дозволяє характеризувати смислову структуру НР. Недоліки семантичних класифікацій НСК полягають у тому, що зазначені конструкції виявляються виокремленими в синтаксичній системі. Семантині критерії розподілу НСК призводять до того, що він здійснюється на засадах, що не співвідносяться 3 підгрунтям типологї всіх інших речень. Об'єктивно кажучи, для НСК створюється начебто власна граматика, що не збігається за принципами структурування із відомою всім граматикою, а, отже, семантичні класифікації НСК не розвязують питання приєднання їх до аналізу інших типів речень, зокрема двоскладних.

Слід також зазначити, що існують також класифікації, побудовані 3 урахуванням стилістичної поліфункціональності НСК (Л. Біятенко, С. Срмоленко, А. Коваль, та ін.). Ця парадигма аналізу особливостей НСК, хоч і не розкриває їх власне граматичні диференційні ознаки, має значення для 3'ясування стилістичної маркованості НСК, вивчення синтаксису тексту.

Аналізуючи НСК-МЖФІ слід надавати перевагу класифікації, що враховує категорійні реченнєві властивості номінативних конструкцій взагалі та їх граматичних особливостей, як малих жанрових форм. В. Пронічев відзначає, що існує два шляхи для створення таких класифікацій: одні дослідники розподіляють НСК на грунті граматичного (модального) значення, оскільки слово перетворюється на речення - номінативну побудову за допомогою інтонації, яка зумовлена метою висловлення чи внаслідок явища парцеляції.

Залежно від інтонації речення набуває певного відтінку модальності. I якщо двоскладному реченню інтонація надає певний модальний відтінок значення, то в номінативному реченні за допомогою інтонації, окрім того, висловлюється предикативність - необхідна ознака будь-якого речення: «...від лат. praedicatio - стверджене, сказане, висловлене - це віднесеність змісту речення до об'єктивної реальності. Предикативність виявляється в ознаках часу, особи, а також в оцінці сказаного оповідачем: бажаність чи небажаність, реальність чи нереальність, упевненість в істинності чи ні» (uk.wikipedia.org/wiki/Предикативність).

Для номінативного речення найважливішим засобом його визначення як синтаксичної одиниці є інтонація, якій належить не лише предикувальна роль, але й модальна, тобто репрезентує відношення мислення і буття. Інші класифікують НСК на підставі репрезентації їх головного члена [6, с. 50]. До перших належать класифікації В. Горпинича, В. Горяного, А. Загнітка, В. Різун та ін. [4]. 3 урахуванням особливостей реалізації головного члена 
НР класифікують їх І. Вихованець, П. Лекант та ін. [3]. Слід враховувати, що ідеальним для будь-якої класифікації є дотримання певного принципу. Превалюючим критерієм відмежування односкладних речень від двоскладних і розмежування односкладних речень в українській мові $\epsilon$ граматичний. Якщо граматичні показники не постають яскравими, вирішальну роль відіграє семантичний принцип класифікації.

Порівнюючи речення Iде! (про виконавця, що виходить на сцену) та Який голос! Який талант!, кваліфікуємо перше речення як двоскладне неповне, а друге - як односкладне, хоч в обох випадках наявний лише один головний член. Підставою для такого розмежування $\epsilon$ різниця в характері висловлених думок. Перше речення легко може бути доповнене підметом - словом виконавець, друге ж речення не потребує жодного словесного доповнення, адже оцінюється якість голосу, природне обдарування людини, яке відобразилося у свідомості співрозмовників у вигляді візуально-емпатичних образів.

Серед засобів експресивного синтаксису малих жанрових форм інформації виділяють: парцельовані конструкції: Артист! Вокаліст! Свген Літвинкович!; Це! Був! Гурт! «Ді-версія»!!! та ін.; лексичний повтор 3 синтаксичним поширенням: Люди, з якими познайомилась, усі талановиті. Вони дружні, вони сердечні. Вони підтримують, розуміють... [7]; питальновідповідально-спонукальні конструкції у монологічному мовленні: То щุо далі? Не боїшся? Вперед!; Відступаєш? Не здаєшся! На сиену! та под [7].

Отже, можемо зробити висновок, що експресивність $є$ функціональною властивістю номінативних синтаксичних конструкцій (НСК)-МЖФІ. Це зумовлено, насамперед, їх виокремленою позицією серед інших малоформатних жанрів, їх позатекстовою семантикою, акцентованою модальністю тощо. Малі жанрові форми інформації (МЖФІ) у сучасній українській мові (на прикладі оголошень ведучих концертів) належать до усного монологічного мовлення і є ілюстративними $з$ погляду загальноприйнятої в лінгвістиці теорії триаспектності повідомлення, що відповідає трьом аспектам мислення, а саме: констатація факту, вираження вольових реакцій, висловлення емоційного ставлення мовця до висловленого. Класифікація МЖФІ не є остаточною і питання ії укладання залишається актуальним. Дослідження експресивного синтаксису набувають динамічного розвитку. Результати дослідження можуть бути використані під час побудови нової синтаксичної теорії диференційованих за спецпризначенням номінативних конструкцій. Практична цінність аналізу визначається тим, що його основні положення і висновки можна використовувати на семінарах і практичних заняттях із теорії і практики синтаксису номінативного й односкладного речення та застосовувати при створенні методичних посібників, рекомендацій для виконання практичних завдань $з$ окресленої тематики. 


\section{Література}

1. Александрова О. В. Проблемы экспрессивного синтаксиса. - М. : Высшая школа, 1984. - $211 \mathrm{c}$.

2. Баранник Д. Х. До питання про «інформаційний» стиль мови / Д. Х. Баранник // Мовознавство. - 1967. - № 6. - С. 3-10.

3.Вихованець I. Р. Семантико-синтаксична структура речення / Вихованець I. Р., Городенська К. Г., Русанівський В. М. - К. : Наук. думка, 1983. - 219 с.

4. Загнітко А. П. Теоретична граматика української мови : Синтаксис : [монографія] / А. П. Загнітко. - Донецьк : ДонНУ, 2001. - 662 с.

5.Кожина М. Н. Стилистика русского языка / М. Н. Кожина. - М. : Просвещение, 1983. $-223 \mathrm{c}$.

6.Проничев В. Г. Типы и модели именных односоставных предложений в современном русском языке / В. Г. Проничев. - Л. : Изд-во ЛГПУ, 1989. - 85 с.

7.Режими доступу : kinofaza.net/news/kh_faktor_3_sezon_2012/2013-01-13-1301]; www.youtube.com

8.Солганик Г. Я. Предисловие / Г. Я. Солганик // Язык современной публицистики : сб. статей [для студентов, аспирантов, преподавателей филолог, ф-тов и ф-тов журналистики] / сост. Г. Я. Солганик. - [2-е изд., исправл.] - М. : Флинта : Наука, 2007. - С. 4-6.

9.Степанова М. М. Роль устойчивых сравнений в формировании семантической структуры газетного текста (на материале французского и русского языков) / М. М. Степанова // Сб. науч. тр. - Вып. 294 : Функции единиц языка в системе текста / ред. кол. : И. Г. Леонтьева (отв. ред.), Э. И. Турчинская (зам. отв. ред.), Э. К. Бурнацева, Л. М. Жданова (отв. секр.). - М. : 1987. - С. 56-63.

10. Чабаненко В. А. Стилістика експресивних засобів української мови : [монографія] / В. А. Чабаненко. - Запоріжжя : ЗДУ, 2002. - 351 с. 